\title{
PENDAMPINGAN DALAM PENGEMBANGAN PEMBINAAN KARAKTER PESERTA DIDIK DI SMPK BINTANG MULIA MEKAR WANGI BANDUNG SEBAGAI SALAH SATU UPAYA PENEGUHAN PANGGILAN HIDUP KRISTEN
}

\author{
Junihot M. Simanjuntak 1), Yanto Paulus ${ }^{2)}$, Victor Deak ${ }^{3)}$, Rivosa Santosa ${ }^{4}$, Anne Yance \\ Pesik $^{5)}$, Dede Raminton ${ }^{6)}$, Lismawati Waruwu ${ }^{7)}$, Riris Ariesta Monalisa Sihite ${ }^{8)}$, Tomas \\ Alianus Lafau' ${ }^{9}$ \\ ${ }^{1,2,3,4)}$ Program Studi Pendidikan Agama Kristen STT Kharisma Bandung \\ 5,6,7,8, 9) Mahasiswa Program Studi Pendidikan Agama Kristen PAK STT Kharisma Bandung \\ 1,2,3,4,5,6,7,8) paksttk@gmail.com
}

\begin{abstract}
Histori artikel
Received:

20 Februari 2021

Accepted:

19 Maret 2021

Published:

19 April 2021

Abstrak

Tujuan dari pengabdian ini adalah: 1) membantu guru bidang studi pendidikan agama Kristen untuk melakukan tugasnya dalam ruang lingkup sekolah dalam melaksanakan tugas membina peserta didik dalam mengembangkan karakter yang terdapat dalam diri peserta didik, menjadi karakter yang sesuai dengan identitas sebagai remaja Kristen. 2) Mengubah moral peserta didik agar berkualitas, dengan memperbaiki dan mengembangkan karakternya, sehingga ia mengalami pembaharuan dan mampu menjadi generasi bangsa pembaharu untuk orang lain dan lingkungan sekitarnya. Bentuk kegiatan ini adalah pendampingan kegiatan pembinaan karakter peserta didik SMPK Bintang Mulia Mekar Wangi Bandung. Peserta dalam kegiatan ini terdiri dari: 1) Guru-guru SMPK Bintang Mulia Mekar Wangi Bandung yang berjumlah 15 orang, 2) Peserta didik Kelas 8 dan 9 yang berjumlah 52 orang, 3) Orangtua (wali) peserta didik berjumlah 52 orang. Kegiatan ini dilakukan dengan metode konseling terjadwal-non formal, demonstrasi, dan latihan. Hasil Kegiatan pendampingan adalah: 1) terjadinya peningkatan kemampuan guru-guru SMPK Bintang Mulia Mekar Wangi Bandung dalam penyusunan perangkat pembelajaran pendidikan karakter kristiani setelah diberikan pelatihan dan pendampingan; dan 2) terjadinya peningkatan keterampilan guru- guru SMPK Bintang Mulia Mekar Wangi Bandung dalam mengimplementasikan pendidikan karakter bangsa setelah diberikan pendampingan.
\end{abstract}

Kata-kata Kunci: pendampingan pembinaan karakter, panggilan hidup kristiani 
Abstract.The objectives of this service are: 1) to help teachers in the field of Christian religious education to carry out their duties within the scope of the school in carrying out the task of fostering students in developing the character contained in students, becoming characters that are in accordance with their identity as Christian adolescents. 2) Changing the morale of students to be quality, by improving and developing their character, so that they experience renewal and are able to become a reformer nation generation for others and the surrounding environment. The form of this activity is the assistance of character building activities for students of SMPK Bintang Mulia Mekar Wangi Bandung. Participants in this activity consisted of: 1) Teachers of SMPK Bintang Mulia Mekar Wangi Bandung, totaling 15 people, 2) Students in Grades 8 and 9, totaling 52 people, 3) Parents (guardians) of 52 students. This activity is carried out using non-formal scheduled counseling methods, demonstrations, and exercises. The results of the mentoring activities are: 1) an increase in the ability of SMPK Bintang Mulia Mekar Wangi Bandung teachers in the preparation of Christian character education learning tools after being given training and mentoring; and 2) there was an increase in the skills of SMPK Bintang Mulia Mekar Wangi Bandung teachers in implementing national character education after being given assistance.

Keywords: mentoring, character building, students, vocation, Christianity.

\section{PENDAHULUAN}

Situasi zaman sekarang menuntut pembinaan dan pendidikan. Nilai zaman yang berubah mengharuskan sekolah melakukan tugas pendidikan dan pengajaran supaya mereka mampu membaca tanda-tanda zaman itu sendiri.

Hasil penelitian yang dilakukan Komisi Nasional Anak di kota-kota besar di Indonesia melaporkan 97\% anak Indonesia pernah nonton pornografi (2009), 30\% kasus aborsi dilakukan remaja usia 15-24 tahun (2009). Badan Narkotika Nasional (BNN) menyebutkan jumlah pengguna narkoba di lingkungan pelajar SD, SMP, SMA pada tahun 2006 mencapai 15.662 anak. Rinciannya untuk tingkat SD sebanyak 1.793 anak, SMP sebanyak 3.543 anak, dan SMA sebanyak 10.326 anak. Belum lagi ditambah akhirakhir ini sering terjadi kasus tawuran antar pelajar/mahapeserta didik, dan lain sebagainya (Turhan Yani, 2011). Pada tahun 2013 angka kenakalan remaja di Indonesia mencapai 6325 kasus, sedangkan pada tahun 2014 jumlahnya mencapai 7007 kasus dan pada tahun 2015 mencapai 7762 . Artinya dari tahun 2013-2014 mengalami kenaikan sekitar 10,7\%, kasus tersebut dari berbagai kasus kenakalan remaja diantaranya, pencurian, pembunuhan, pergaulan bebas dan narkoba. Dari data tersebut dapat diprediksi jumlah peningkatan angka kenakalan remaja setiap tahunnya. Prediksi tahun 2019 mencapai 11685,90 kasus dan pada tahun 2020 mencapai 12944,47 kasus. Mengalami kenaikan tiap tahunnya sebesar 10,7\%. Menurut Badan Pusat Statistik (BPS) dari 233 juta jiwa penduduk Indonesia, 28,6\% atau 63 juta jiwa adalah remaja berusia 10-24 tahun (BPS, 2017). Perilaku hidup yang demikian menjadi karakter masyarakat modern yang pada akhirnya melahirkan kesenjangan sosial yang berkepanjangan (Kazuo Shimogak, 2000). Dalam hal inilah Allah menuntut semua orang beriman untuk belajar dan berbuat untuk dirinya sendiri dan untuk orang lain juga bagi kemuliaan Allah (Junihot M. Simanjuntak, 2018).

Berdasarkan hasil temuan Lawrence E. Shapiro (1997: 10-11), penelitian-penelitian terakhir mengungkapkan bahwa: Saat ini banyak orangtua yang berusaha keras membuat anak-anaknya lebih cerdas, atau paling tidak menghasilkan nilai lebih baik dalam uji-uji IQ standart. Menurut Hariyanto (2018), banyak orang berpikir bahwa anak yang kecerdasan intelektualnya tinggi terjamin sukses di masa depan, itulah sebabnya para orang tua saat ini berlomba-lomba untuk dapat menyekolahkan anaknya di sekolah yang bermutu tinggi meskipun dengan biaya yang sangat tinggi. Selama ini kecerdasan intelektual seringkali dijadikan patokan untuk memprediksi kesuksesan seseorang di masa depan. Lebih lanjut James R. Flynn (dalam Plucker, 2003) mengemukakan bahwa angka IQ telah meningkat lebih dari dua puluh poin sejak pertama kali digunakan pada awal abad ini, suatu temuan yang menyimpang dari pola evolusi yang kita kenal. Flynn mencatat bahwa hal ini disebabkan oleh perubahan sikap orangtua dalam membesarkan anak setelah Perang Dunia II. Namun ironisnya, sementara dari generasi ke generasi anak-anak semakin cerdas, keterampilan emosional dan sosialnya merosot tajam. 
Di Indonesia hasil survei BKKBN tahun 2008 menyebutkan bahwa 63\% remaja di beberapa kota besar telah melakukan seks pranikah. Tingginya angka hubungan seks berkorelasi dengan meningkatnya jumlah aborsi, tercatat sekitar 2,3 juta atau 20\% diantaranya dilakukan oleh remaja (Yanur Setyaningrum, 2011). Lebih lanjut, berdasarkan hasil penelitian Rasid Ansari, Linda Suwarni, Selviana, Rochmawati, dan Mawardi (2020), prevalensi remaja yang melakukan seks pranikah sebesar $41 \%$, dan angka ini menunjukkan tren peningkatan dari tahun ke tahun. Prevalensi remaja yang melakukan seks pranikah sebesar $4,5 \%$ untuk laki-laki dan $0,7 \%$ untuk perempuan, sekitar 9,3\% atau 3,7 juta remaja menyatakan pernah melakukan hubungan seksual pranikah. Angka ini meningkat pada tahun 2017, dimana 50\% remaja laki-laki dan perempuan 30\% mengaku pernah melakukan hubungan seks pranikah.

Menurut Thomas Lickona, anak-anak usia SD menghabiskan waktu dalam seminggu di depan televisi sebanyak 30 jam. Saat berusia 16 tahun, rata-rata anak-anak akan menyaksikan sekitar 200.000 adegan kekerasan, dan pada usia 18 tahun mereka akan menyaksikan setidaknya 40.000 gambar yang merangsang secara seksual (Anastasia Toufexix , 1989). Theresa Orange dan Louise O'Flynn (Orange, 2005) dalam buku The Media Diet for Kids menyebutkan hasil perilaku yang diperoleh dari praktik menonton TV antara lain perilaku anti sosial, apatis, anak mulai paham dan mengetahui seks secara samar, dewasa dini, dan terjadinya ketidakseimbangan energi. Dalam teori belajar sosial Albert Bandura dijelaskan bahwa anak belajar menggunakan model. Model dimaksud adalah apa yang dilihat, dialami dan didengar dari orang dewasa. Anak akan melakukan hal serupa sebagaimana yang dilakukan oleh orang tua, guru dan orang dewasa lainnya. Melalui media baru, perilaku orang dewasa saat ini telah tersubsitusi dalam sebuah tontonan yang ada dalam layar kaca baik di televisi atau gadget. Jadi, anak juga akan menjadikan televisi dan totonan dalam gadget sebagai model untuk diduplikasi (Ulfah, 2019).

Di Amerika Serikat, munculnya gerakan nasional pendidikan karakter sejak tahun 1990-an, tak lepas dari kesadaran berbagai pihak terhadap tanda-tanda keruntuhan moral masyarakat pada umumnya dan khususnya moral kaum muda (Thomas Lickona, 2013:1214). Ketika itu, mereka sangat prihatin terhadap meningkatnya kejahatan, bunuh diri di kalangan remaja, perceraian, aborsi, kebiasaan menyontek di kalangan siswa, kebiasaan mencuri barang di toko di kalangan remaja, dan lain-lain.

Hal serupa kini terjadi di Indonesia. Berbagai pihak menyuarakan tentang pentingnya pendidikan karakter. Pendidikan karakter dianggap sebagai salah satu cara penting untuk mengatasi kerusakan moral masyarakat yang sudah berada pada tahap sangat mencemaskan.

Sekolah sebagai lembaga pendidikan sudah seharusnya memperhatikan akan masalah ini. Guru-guru SD Bintang Mulia secara khusus, harus belajar menjadi pembina, menjadi teladan dalam hal karakter dan tata nilai para siswanya guna mempersiapkan mereka sebagai anak-anak Tuhan yang dapat menjadi berkat bagi keluarga, gereja, bangsa dan negara, juga bagi dunia.

Guru harus memiliki kesadaran bahwa tugas guru tidak hanya datang kesekolah, berbincang-bincang, masuk kelas memberikan materi tanpa memikirkan tugas utama yaitu mendidik anak-anak dalam mengembangkan karakter. Sebagai guru kristen kita harus sadar bukan hanya berbicara tentang doktrin yang kita terima, tetapi berkaitan dengan masalah sikap hidup sehari-hari, yang mesti ditandai oleh perubahan karakter terus menerus, itulah sebagai refleksi iman kita kepada Tuhan di dalam Yesus Kristus.

Oleh karena itu sangat tepat kiranya jika Program studi Strata Satu Pendidikan Agama Kristen Sekolah Tinggi Teologi Kharisma merasa terpanggil untuk mendampingi guru dan peserta didik di SMPK Bintang Mulia dalam pengembangan pembinaan karakter peserta.

Kegiatan ini bertujuan untuk memberikan pendampingan kepada guru bidang studi pendidikan agama Kristen dalam melakukan pembinaan karakter bagi peserta didik di SMPK Bintang Mulia Mekar Wangi Bandung melalui kegiatan belajar di dalam kelas. Kegiatan ini dilakukan dengan metode pendampingan dan pelatihan. Pendampingan ini melibatkan guru-guru SMPK Bintang Mulia Mekar Wangi Bandung yang berjumlah 15 
orang, perserta didik Kelas 8 dan 9 yang berjumlah 52 orang, dan Orangtua (wali) peserta didik berjumlah 52 orang.

Kegiatan ini mempunyai 3 tujuan pokok, yaitu: 1) membantu guru bidang studi pendidikan agama Kristen untuk melakukan tugasnya dalam ruang lingkup sekolah dalam melaksanakan tugas membina peserta didik dalam mengembangkan karakter yang terdapat dalam diri peserta didik, menjadi karakter yang sesuai dengan identitas sebagai remaja Kristen. 2) Mengubah moral peserta didik agar berkualitas, dengan memperbaiki dan mengembangkan karakternya, sehingga ia mengalami pembaharuan dan mampu menjadi generasi bangsa pembaharu untuk orang lain dan lingkungan sekitarnya.

\section{METODE PELAKSANAAN}

Untuk memecahkan masalah yang sudah diidentifikasi dan dirumuskan, agar pendampingan dapat berjalan dengan lancar maka sebagai alternatif pemecahan masalah adalah pendampingan dilakukan dengan pendekatan konseling formal dan non formal. Konseling secara formal yaitu lewat pertemuan di kelas, dan juga sheperding selama seminggu sekali untuk setiap kelasnya, dan juga ada melakukan bimbingan BK di ruang yang sudah ditentukan dan konseling secara nonformal bertemu saat pembelajaran tidak berlangsung atau berpapasan saat beristirahat ataupun chat secara pribadi di media sosial. Lewat pendekatan ini kita akan mempunyai target dalam mencapai sebuah karakter yang baik, supaya ketika nanti mereka keluar dari SMPK Bintang Mulia, peserta didik itu akan menjadi satu lulusan yang tidak hanya berprestasi baik tapi juga mempunyai karakter yang luar biasa seperti Kristus Yesus.

Adapun metode yang digunakan adalah:

1) Konseling terjadwal/non formal. Metode ini digunakan untuk membantu dalam pengenalan akan setiap pribadi peserta didik dalam pembinaan karakter ini, konseling yang di lakukan secara tidak formal, yang dilaksanakan di pada saat mengajar, hal ini bermaksud untuk membantu guru dalam mengetahui masalah dan kesulitan yang dihadapi peserta didik, baik di rumah maupun di sekolah.

2) Demonstrasi. Metode ini dipilih untuk menunjukkan suatu proses kerja yaitu tahaptahap pembinaan karakter dan diaplikasikan ke dalam dasar-dasar panggilan bagi seorang pendidik dan iman Kristen. Demonstrasi dilakukan oleh instruktur di hadapan para guru terkait dalam mendesain kurikulum tentang pembinaan karakter dan tata nilai kepada para peserta didik di SMPK Bintang Mulia Bandung dalam menunjang berhasilnya tujuan pendidikan SMPK Bintang Mulia Bandung sebagai sekolah yang mendukung generasi penerus pendidikan dan imam-imam Kristen di masa depan yang memiliki karakter yang baik.

3) Latihan. Metode ini digunakan untuk memberikan tugas kepada peserta pendampingan untuk mempraktekkan kurikulum pendidikan karakter SMPK Bintang Mulia Bandung.

Khalayak sasaran dalamkegiatan ini adalah guru bidang studi pendidikan

Agama Kristen, peserta didik, dan orangtua (wali peserta didik) di SMPK Bintang Mulia Bandung. Sejalan dengan cara pemecahan masalah yang ditempuh, maka sejumlah metode diterapkan dalam kegiatan ini (Laksana, Dinatha, dan Upayogi, 2020). Metode yang digunakan dalam kegiatan ini adalah metode pendampingan dan pelatihan. Deskripsi program dan indikator ketercapaian program disajikan dalam Tabel 1 sebagai berikut.

Tabel 1. Deskripsi Program dan Indikator Ketercapaian Program

\begin{tabular}{cllll}
\hline No & \multicolumn{1}{c}{ Program } & \multicolumn{2}{c}{$\begin{array}{c}\text { Deskripsi pelaksanaan } \\
\text { kegiatan }\end{array}$} & Indikator Ketercapaian \\
\hline 1 & $\begin{array}{l}\text { Pendampingan } \\
\text { belajar di dalam } \\
\text { dan di luar kelas }\end{array}$ & $\begin{array}{l}\text { Kegiatan ini dilakukan } \\
\text { dengan } \\
\text { peserta didik dalam } \\
\text { belajar }\end{array}$ & $\begin{array}{l}\text { Kualitas karakter } \\
\text { pristiani } \\
\text { berkembang dalam hal: } \\
\text { dengan hormat dan menyembah }\end{array}$
\end{tabular}


menggunakan pembelajaran inovatif.

\section{Respon guru,} peserta didik, orangtua (wali)

Peserta didik dalam kegiatan

pendampingan pembinaan karakter peserta didik model Tuhan, menjalankan tugas

kreatif- dan kewajibanya dengan baik, mampu berkomunikasi dengan menjadi pendengar yang baik, mampu bekerja mandiri dan bersama-sama, dan tahan terhadap stres.
Melakukan
terbuka
wawancara
pelaksanaan
terkait
pendampingan
pembinaan karakter
peserta didik di dalam
kelas.

Guru, peserta didik dan orang tua memberikan respon yang positif.

\section{HASIL DAN PEMBAHASAN \\ Hasil}

Kegiatan pendampingan dilakukan guru-guru SMPK Bintang Mulia Mekar Wangi Bandung yang berjumlah 15 orang, perserta didik Kelas 8 dan 9 yang berjumlah 52 orang, dan Orangtua (wali) peserta didik berjumlah 52 orang. Kegiatan ini dilakukan dengan metode pendampingan belajar di dalam dan di luar kelas.

Kegiatan dilaksanakan selama satu bulan, yaitu tanggal 8 September sampai 8 Desember 2019. Kegiatan ini menjalankan program pendampingan pendidikan karakter bagi peserta didik yang dilaksanakan di dalam dan di luar kelas, dengan mekanisme kegiatan adalah, surat permohonan dari Prodi PAK STT Kharisma Bandung diajukan kepada pihak Yayasan penyelenggara pendidikan SMPK Bitang Mulia Mekar Wangi Bandung melalui Kepala Sekolah SMPK Bitang Mulia Mekar Wangi Bandung pada tanggal 27 Juli 2019, selanjutnya dilakukan rapat pemantapan panitia di tingkat Prodi PAK STT Kharisma, mengikuti kegiatan pertemuan pemantapan dengan kepala sekolah dan guru bidang studi pendidikan agama Kriste SMPK Bitang Mulia Mekar Wangi Bandung. Pada tanggal, 11 Agustus 2019 kembali di adakan rapat bersama untuk persiapan pelaksanaan pendampingan pembinaan karakter bagi peserta didik di SMPK Bitang Mulia Mekar Wangi Bandung, pemeriksaan hasil pelaksanaan, dan mengevaluasi hasil pelaksanaan.
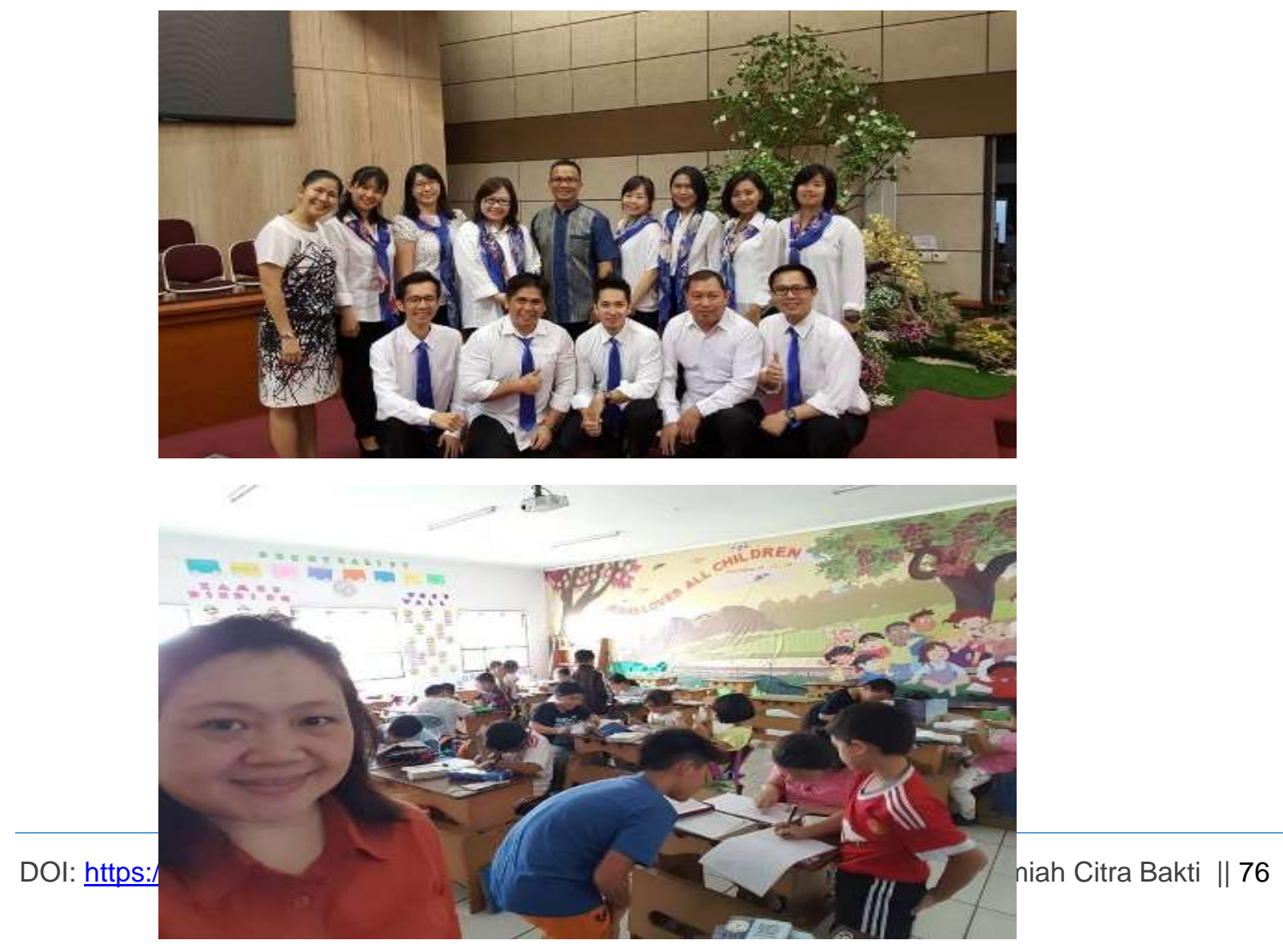


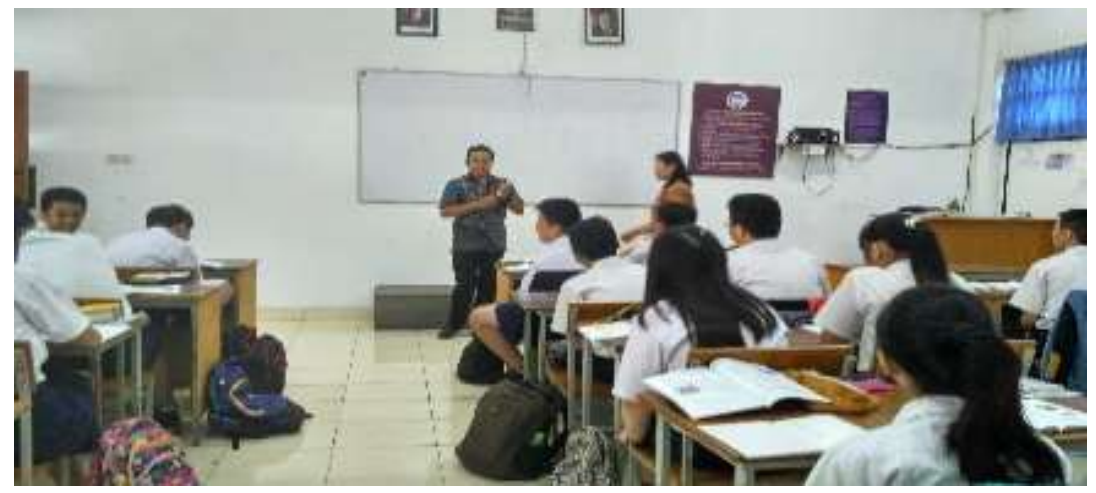

\section{Gambar: Kegiatan Pendampingan Guru PAK dalam Pembinaan Karakter Peserta Didik Di SMPK Bitang Mulia Mekar Wangi Bandung}

Adapun Tahap kegiatan pembinaan karakter peserta didik SMPK Bitang Mulia Mekar Wangi Bandung, tampak sebagaimana disajikan pada Tabel 2 berikut.

Tabel 2. Tahap Kegiatan Pelaksanaan Pendampingan Pembinaan Karakter

\begin{tabular}{|c|c|c|c|c|}
\hline No & Deskripsi Kegiatan & Waktu & Tempat & Keterangan \\
\hline 1 & $\begin{array}{l}\text { Surat Permohonan dari } \\
\text { Ketua Prodi PAK STT } \\
\text { Kharisma kepada } \\
\text { Yayasan Kalam Kudus } \\
\text { melalui perantaraan } \\
\text { Kepala Sekolah SMAK } \\
\text { Kalam Kudus Mekar } \\
\text { Wangi Bandung }\end{array}$ & 27 Juli 2019 & $\begin{array}{l}\text { Prodi PAK STT } \\
\text { Kharisma } \\
\text { Bandung }\end{array}$ & Terlaksana \\
\hline 2 & $\begin{array}{l}\text { Rapat Pembentukan } \\
\text { Panitia }\end{array}$ & 11 Agustus 2019 & $\begin{array}{l}\text { Prodi PAK STT } \\
\text { Kharisma } \\
\text { Bandung }\end{array}$ & Terlaksana \\
\hline 3 & $\begin{array}{l}\text { Penyusunan Analisis } \\
\text { Situasi }\end{array}$ & 14 Agustus 2019 & $\begin{array}{l}\text { SMPK Bitang } \\
\text { Mulia Mekar } \\
\text { Wangi Bandung }\end{array}$ & Terlaksana \\
\hline 3 & $\begin{array}{l}\text { Penyusunan Materi } \\
\text { Pendampingan }\end{array}$ & 19 Agustus 2019 & $\begin{array}{l}\text { Prodi PAK STT } \\
\text { Kharisma } \\
\text { Bandung }\end{array}$ & Terlaksana \\
\hline 4 & $\begin{array}{l}\text { Rapat Pemantapan } \\
\text { Panitia }\end{array}$ & 20 Agustus 2019 & $\begin{array}{l}\text { SMPK Bitang } \\
\text { Mulia Mekar } \\
\text { Wangi Bandung }\end{array}$ & Terlaksana \\
\hline 5 & $\begin{array}{l}\text { Pelaksanaan } \\
\text { Pendampingan Kegiatan } \\
\text { Pembinaan Karakter } \\
\text { Peserta Didik SMAK } \\
\text { Kalam Kudus Mekar } \\
\text { Wangi Bandung }\end{array}$ & $\begin{array}{l}8 \text { September sampai } \\
8 \text { Desember } 2019\end{array}$ & $\begin{array}{l}\text { SMPK Bitang } \\
\text { Mulia Mekar } \\
\text { Wangi Bandung }\end{array}$ & Terlaksana \\
\hline 6 & Evaluasi hasil Kegiatan & 10 Desember 2019 & $\begin{array}{l}\text { Prodi PAK STT } \\
\text { Kharisma } \\
\text { Bandung }\end{array}$ & Terlaksana \\
\hline
\end{tabular}


Tahap Pelaksanaan Tugas Guru Sebagai Pembimbing. Dalam pelaksanaan ini tim panitia memberikan pelatihan terlebih dahulu pada guru bidang studi pendidikan agama Kristen Kalam Kudus Bandung agar mampu mengimplementasikan pembinaan karakter kepada peserta didik. Berikut ini adalah tahapan-tahapan materi yang diberikan.

Tahap pertama pengajaran: Penginjilan.Tahap ini diberikan agar guru-guru yang mengajar di SMPK Bitang Mulia Mekar Wangi Bandung memahami langkah pertama yang dilakukan dalam memberikan pembinaan kaarakter bagi peserta didiknya yang diintegrasikan dengan bidang studi yang diampunya.

Pembinaan karakter dalam konteks pendidikan Kristen selalu dimulai dengan menanyakan keadaan rohani orang yang bermasalah. Penyebabnya ialah penyelesaian suatu masalah tidak akan sempurna jika tanpa pertolongan ilahi dan tidak sesuai dengan firman Allah. Tahap kedua pendidikan: Pembentukan kepribadian

Tahap ini diberikan sebagai tahap lanjutan dari tahap pertama. Untuk menjernihkan perspektif kita tentang pendidikan dan bimbingan anak, sangat berfaedah jika kita memikirkan tugas pendidikan yang diperintahkan Allah kepada umat Israel. Dasar itu diletakkan dalam Ulangan 6:4-9. Ayat ini dikenal dengan istilah "shema", syahadat iman yang harus dihafalkan dan dipelajari oleh setiap anak Israel. Syahadat itu berbunyi "Tuhan itu Allah kita, Tuhan itu esa! Kasihilah Tuhan Allahmu dengan segenap hatimu dan dengan jiwamu dan dengan segenap kekuatanmu".

Setelah memberikan pendampingan bagi guru, selanjutnya tim memberikan materi pembinaan berupa tugas-tugas yang harus dilakukan oleh peserta didik.

Berdasarkan serangkaian kegiatan interviu, wawancara mendalam, observasi, dan PRA dengan menggunakan instrumen tingkat kemampuan guru dalam melkasanakan pembinaan karakter yang disusun berdasarkan indikator perilaku (a) persiapan mengajar, (b) kegiatan belajar mengajar, (c) hubungan sosial, dan (d) kreativitas. Hasilnya dipaparkan berikut ini.

Tingkat perubahan perilaku dan kompetensi yang terjadi pada guru SMPK Bitang Mulia Mekar Wangi Bandung binaan setelah mengikuti program pelatihan.

Tingkat perubahan perilaku dan kompetensi yang terjadi pada guru SMPK Bitang Mulia Mekar Wangi Bandung binaan setelah mengikuti program pelatihan, dikelompokkan menjadi tiga bagian, yaitu (a) tingkat perubahan perilaku dan kompetensi sebelum pelatihan, (b) tingkat perubahan perilaku dan kompetensi sesudah pelatihan, dan (c) tingkat perubahan perilaku dan kompetensi dari sebelum hingga sesudah pelatihan.

Berdasarkan kondisi kendala utama/pokok dalam mewujudkan setelah mengikuti pelatihan dapat disimpulkan sebagai berikut: (a) ada keterbatasan sarana utama pelaksanaan pembinaan karakter di sekolah (silabus, rancangan pembelajaran, dan materi/bahan ajar), (b) guru kurang kreatif dalam menyikapi keterbatasan sarana utama pembinaan karakter peserta didik, (c) peserta didiik kurang termotivasi untuk mengikuti kegiatan pembinaan karakter secara optimal, (d) guru belum memiliki kemampuan komptensi yang optimal untuk membangkitkan motivasi siswa agar menyenangi setiap kegiatan pembinaan karakter, (e) guru masih mengalami kesulitan dalam menguasai konsep dasar pembinaan karakter yang terintegrasi dengan mata pelajaran yang diampunya dan mengalami keterbatasan dalam menguasai strategi dan media pembelajaran, (f) guru belum terampil dalam melakukan

kegiatan pembinaan karakter, dan (g) guru belum terampil mengevaluasi kegiatan pembinaan karakter secara menyeluruh.

Sedangkan kendala penunjang yang ada yaitu: (a) lemahnya team teaching dalam pelaksanaan program pembinaan karakter, (b) kurangnya pengawasan kepala sekolah untuk mengevaluasi kinerja guru, (c) guru dan peserta didik telah terbiasa dengan karakter bawaan yang terbentuk dari rumah dan lingkungannya, sehingga mereka mengalami kesulitan dalam menentukan sikap dan tindakan yang sesuai dengan apa yang diterimanya dalam pembinaan karakter yang diselenggarakan di sekolah, (d) masih lemahnya dukungan kepala sekolah dalam membina perilaku guru, dan (e) orang tua siswa kurang memberikan dukungan bagi terselenggaranya kegiatan pembinaan karakter di sekolah, karena kurang dilibatkan oleh pihak sekolah. 


\section{Alternatif yang dapat dilakukan guru dalam meningkatkan kompetensi guru dalam penyelenggaraan program pembinaan karakter peserta didik setelah mengikuti program pelatihan.}

Data tentang alternatif-alternatif yang dapat dilakukan guru dalam meningkatkan kompetensi setelah mengikuti program pelatihan dikelompokkan menjadi dua bagian yaitu: (a) alternatif utama/pokok dan (b) alternatif penunjang.

Berdasarkan hasil evaluasi pelaksanaan pelatihan pendampingan pembinaan karakter peserta didiik di SMPK Bitang Mulia Mekar Wangi Bandung dapat disimpulkan sebagai berikut. Pertama, alternatif utama/pokok yang perlu dilakukan menurut guru-guru SMPK Bitang Mulia Mekar Wangi Bandung adalah: (a) guru mengaktifkan kegiatan KKG untuk melatih keterampilan penguasaan konsep program pembinaan karakter dan penyelenggaraan kegiatan belajar mengajar, (b) guru secara bersama-sama terlibat dalam menyusun Silabus, RPP dan materi kegiatan pembinaan karakter, (c) antarguru melakukan diskusi intensif untuk membahas silabus, rpp dan materi serta strategi pembinaan karakter yang tepat, (d) diskusi rutin antarguru untuk mencari solusi keterbatasan kreativitas dan upaya memotivasi peserta didik, (e) guru mengupayakan terselenggaranya KKG secara optimal, sehingga segala permasalahan yang ditemukan pada implementasi program pembinaan karater yang diselenggaran sekolah pada masing-masing kelas dapat teratasi, (f) guru mengoptimalkan pola pentemuan KKG dengan formasi isi pertemuan secara bervariasi sesuai dengan permasalahan yang tengah dihadapi guru, (g) kepala sekolah SMPK SMPK Bitang Mulia Mekar Wangi Bandung mengusahakan ketercukupan ketersedianaan sarana pembelajaran utama yang dibutuhkan untuk menunjang suksesnya program pembinaan karakter yang diselenggarakan oleh para guru, (h) guru bersama-sama dengan peserta didik mencoba untuk mengatasi keterbatasan media pembelajaran dengan menggunakan pola karya sendiri.

Kedua, alternatif penunjang yang dapat dilakukan yaitu: (a) mengundang fasilitator/nara sumber dalam kegiatan KKG (dalam hal ini dosen-dosen prodi PAK berperan sebagai narasumber yang membantu para guru dalam mengatasi keterbatasannya), (b) mendorong agar kepala dan para wakil kepala sekolah untuk membuat supervisi pelaksanaan pembinaan karakter secara terprogram, (c) guru berlatih untuk mengembangkan diri dengan belajar bersama guru dari sekolah mitra, (d) guru bersama kepala sekolah dan wakil kepala sekolah membuat kesepakatan pertemuan setiap han Sabtu untuk mengevaluasi seluruh aktivitas kegiatan pembinaan karakter yang sudah diselenggarakan setiap minggu, (d) mengundang orang tua untuk hadir di sekolah sekaligus memikirkan cara yang terbaik mengembangkan kualitas pembinaan karakter peserta didik yang sudah ada, (e) kepala memfasilitasi guru untuk membentuk team teaching yang berguna bagi pengembangan kompetensi guru dalam pembinaan karakter peserta didik, (f) guru bersama kepala sekolah mengupayakan implementasi kerja team teaching secara optimal.

Motivasi guru, peserta didik dan orangtua peserta didik binaan untuk meningkatkan mutu program pembinaan karakter di sekolah setelah mengikuti program pelatihan pembinaan karakter peserta didik.

Data tentang tingkat motivasi guru, peserta didik dan orangtua peserta didik binaan untuk meningkatkan mutu program pembinaan karakter di sekolah setelah mengikuti program pelatihan yang dipaparkan dapat dilihat pada Tabel 3 berikut.

Tabel 3. Tingkat motivasi guru dan peserta didik binaan untuk meningkatkan mutu program pembinaan karakter setelah mengikuti program pelatihan

\begin{tabular}{clccc}
\hline \multirow{2}{*}{ No. } & \multirow{2}{*}{ Peserta Pelatihan } & \multicolumn{3}{c}{ Tingkat motivasi guru dan peserta didik } \\
& Perencanaan & Pelaksanaan & Evaluasi \\
\hline 1 & Guru & $87 \%$ & $87 \%$ & $82 \%$ \\
2 & Peserta didik & $83 \%$ & $85 \%$ & $80 \%$ \\
3 & Orangtua peserta didik & $90 \%$ & $90 \%$ & $90 \%$ \\
\hline
\end{tabular}

Untuk memastikan agar apa yang telah diperoleh guru, peserta didik, dan orangtua peserta didik selama pelatihan dapat diwujudkan dengan tepat pada kinerja dan kegiatan 
peserta didik sehari-hari (disekolah dan di luar sekolah), maka perlu dilakukan pendampingan. Pendampingan dapat dilakukan oleh pihak orangtua peserta didik ataupun bekerja sama dengan pihak pelaksana pelatihan (dalam hal ini prodi PAK STT Kharisma Bandung). Pendampingan yang efektif diawali dengan kesepakatan bersama antara pendamping dengan yang didampingi dlam kerangka supervisi klinis. Kesepakatan supervisi klinis tersebut sekaligus dijadikan sebagai dasar dalam rangka menyelenggarakan evaluasi kinerja guru, peserta didik dan orangtua peserta didik.

\section{Pembahasan}

Para guru mempunyai tugas yang sangat penting dalam membina karakter anakanak. Bimbingan yang baik oleh seorang guru dapat mengoreksi sebagian dampak kelalaian orang tua yang kurang bertanggung jawab. Kedudukan seorang guru yang sebenarnya ialah sebagai wakil/wali orang tua anak didik. Guru, yang mewakili orangtua sepanjang puluhan jam setiap minggu, seyogianya menunjang usaha mereka (orang tua) supaya kedua konteks pembinaan itu tidak menimbulkan kontrodiksi di ranah pengertian sang anak.

Guru memiliki peran yang sangat penting baik dalam pembentukan karakter maupun pembelajaran. Peserta didik memerlukan peran seorang guru untuk membantunya dalam proses perkembangan diri dan pengoptimalan bakat dan kemampuan yang dimiliki peserta didik. Tanpa adanya seorang guru, mustahil seorang peserta didik dapat mewujudkan tujuan hidupnya secara optimal. Hal ini berdasar pada pemikiran manusia sebagai makhluk sosial yang selalu memerlukan bantuan orang lain untuk mencukupi semua kebutuhannya. Mulyasa mengidentifikasi sedikitnya sembilan belas peran guru dalam pembelajaran diantaranya adalah guru sebagai pendidik, pengajar, pembimbing, pelatih, penasehat, pembaharu (innovator), model dan teladan, pribadi, peneliti, pendorong kreativitas, pembangkit pandangan, pekerja rutin, pemindah kemah, pembawa cerita, aktor, emansivator,evaluator, pengawet, dan sebagai kulminaor (Ahmad Susanto, 2016: 32).

Dalam penerepan kurkulum 2013, program pendidikan karakter harus diintegrasikan oleh guru dalam kegiatan pembelajaran sesuai dengan bidang studi yang diampunya. Kegiatan lain yang menjadi wadah bagi pendidikan karakter adalah kegiatan rutin ekstrakulikuler sekolah, seperti pramuka, upacara bendera, dan kegiatan keagamaan. Kegiatan-kegiatan yang terlaksana di sekolah tersebut mengajarkan pendidikan karakter dengan berbagai metode, seperti pemodelan, pengajaran langsung, dan memberi reward. Hal ini sesuai dengan pendapat Ajat Sudrajat (2011) mengenai metode yang bisa digunakan untuk pengajaran pendidikan karakter yakni pemodelan, pengajaran, dan pemberian penguat. Alhairi (2015) juga menyatakan bahwa metode yang bisa digunakan untuk pendidikan karakter adalah afirmasi, pembelajaran langsung, kegiatan kooperatif, pembiasaan, dan pemberian reward.

Proses manajemen pemberdayaan yang baik menghasilkan produk manajemen kompetitif sehingga proses dan hasilnya dalam kategori berkualitas (Junihot M. Simanjuntak, Udin Syaefuddin Sa'ud, Aan Komariah, 2019:112). Oleh sebab itu pengembangan program akademik dan non akademik dalam pengajaran pendidikan karakter memerlukan rancangan yang terstruktur. Implikasi aktivitas nyata adalah adanya program yang terencana dan terstruktur dalam pelaksanaan pendidikan karakter di sekolah dari perencanaan hingga evaluasi. Pelibatan seluruh komponen sekolah berimplikasi pada adanya sistem dan struktur pelaksana program pendidikan karakter di sekolah. Mulai dari menetapkan tim pengembang dan peran masing-masing tim, melakukan komunikasi efektif dalam implementasi program, konferensi kasus untuk mengkaji kemajuan, dan bahkan memberi pelatihan pada seluruh tim yang terlibat (Ajat Sudrajat, 2011).

Namun demikian, persoalan yang menjadi pendampingan ini adalah meskipun sekolah telah memiliki program akademik dan non akademik yang bisa dimanfaatkan untuk pengembangan pendidikan karakter, namun selama ini guru di sekolah belum pernah menyusun perencanaan yang jelas mengenai pengembangan pendidikan karakter. Di lain pihak, siswa berkebutuhan khusus seringkali memiliki hambatan kognisi, emosi, dan atau perilaku yang menjadi persoalan khusus dalam mengembangkan nilai karakter positif pada diri mereka. Oleh karena itu, maka pelaksanaan program pendidikan karakter bagi peserta didik seharusnya sesuai dengan prinsip pelaksanaan pendidikan bagi individual mereka 
yakni, bersifat akomodatif, tanggap, berkesinambungan sepanjang perkembangan anak, dan komprehensif terhadap kebutuhan khusus anak (Hallahan dkk., 2009).

Artinya, program pendidikan karakter bagi peserta didik yang dilaksanakan oleh guru yang melibatkan orangtua peserta didik sebaiknya didahului oleh asesmen kebutuhan pengembangan sikap dan perilaku mereka. Asesmen kebutuhan dimulai dari memahami kelebihan dan kekurangan sikap dan perilaku masing-masing anak untuk kemudian menjadi dasar pengembangan atau pemilihan perilaku yang mencerminkan karakter positif. Perilaku yang diajarkan bisa dipilih dari perilaku yang paling sederhana menuju pada perilaku yang kompleks serta perilaku yang konkrit menuju pada perilaku yang lebih abstrak.

Pengembangan program akademik dan non akademik dalam pengajaran pendidikan karakter memerlukan rancangan yang terstruktur. Implikasi aktivitas nyata adalah adanya program yang terencana dan terstruktur dalam pelaksanaan pendidikan karakter di sekolah dari perencanaan hingga evaluasi. Pelibatan seluruh komponen sekolah berimplikasi pada adanya sistem dan struktur pelaksana program pendidikan karakter di sekolah. Mulai dari menetapkan tim pengembang dan peran masing-masing tim, melakukan komunikasi efektif dalam implementasi program, konferensi kasus untuk mengkaji kemajuan, dan bahkan memberi pelatihan pada seluruh tim yang terlibat (Ajat Sudrajat, 2011).

Peningkatan pemahaman dan keterampilan peserta terkait dengan pengembangan pendidikan karakter untuk peserta didik meningkat sampai $12 \%$. Adapun faktor utama yang menyebabkan peningkatan ini adalah karena disebabkan pola pendampingan pengembangan pendidikan karakter dilakukan berdasarkan konsistensi semua pihak pada nilai-nilai luhur yang terkandung dalam ajaran agama Kristiani yang bersumber pada Alkitab. Dimana ajaran agama tidak hanya dijadikan sebagai sekedar alat legitimasi para pembina rohani, dimana pemikiran, praktik-praktik, dan pranata-pranata keagamaan tetap dan konsisten dijadikan sebagai pusat kehidupan (Bryan R. Wilson, 1969). Dalam teori belajar sosial Albert Bandura dijelaskan bahwa anak belajar menggunakan model. Model dimaksud adalah apa yang dilihat, dialami dan didengar dari pembinanya (dalam hal ini Guru dan Orangtua). Anak akan melakukan hal serupa sebagaimana yang dilakukan oleh guru dan orang tua (Ulfah, 2019).

Hal ini menandakan bahwa pelatihan bagi guru mengenai pengembangan program pendidikan karakter bagi peserta didik peserta didik di sekolah perlu dilakukan. Pelatihan yang melibatkan seluruh tim yang terlibat dalam program pendidikan karakter di sekolah menjadi aspek yang perlu diterapkan dalam implementasi program (Ajat Sudrajat, 2011).

\section{KESIMPULAN}

Pendampingan guru untuk menyusun dan mengimplementasikan program pendidikan karakter bagi peserta didik di SMPK Bintang Mulia Mekar Wangi Bandung ini dilaksanakan dalam empat tahapan, yakni 1) Penjelasan konsep program pendidikan karakter Kristiani bagi peserta didik di sekolah; 2) asesmen kebutuhan sekolah dan asesmen terhadap kebutuhan program bagi peserta didik dan orangtua peserta didik; 3) simulasi kasus dan penyusunan contoh rancangan program; 4) penugasan menyusun program pendidikan karakter untuk pesert didik sesuai kondisi pesert didik di SMPK Bintang Mulia Mekar Wangi Bandung; 5) evaluasi kinerja guru.

Beberapa alternatif yang dilakukan guru untuk meningkatkan perilaku profesionalnya, meliputi alternatif utama yaitu inisiatif guru secara individu maupun kelompok untuk membentuk KKG sebagai wadah bagi guru untuk melakukan peningkatan kaulitas konsep dasar program pendidikan karakter. Kegiatan yang dapat dilakukan melalui KKG, meliputi diskusi rutin antarguru untuk mencari solusi keterbatasan kreativitas dan upaya memotivasi peserta didik dalam mengikuti program pembinaan karakter; melatih keterampilan penguasaan konsep pembinaan dan penyelenggaraan kegiatan belajar mengajar pada bidang studi yang diampu guru yang diintegrasikan dengan pembinaan karakter; dan guru bersama-sama peserta didik mencoba untuk mengatasi keterbatasan media pembelajaran dengan menggiinakan pola karya sendiri.

Pada bagian pelaksanaan dan evaluasi pelatihan program pembinaan karakter, diperoleh data yang lebih baik dibandingkan dengan perencanaan program pembinaan karakter. Hal mi dapat diartikan bahwa para guru di SMPK Bintang Mulia Mekar Wangi 
Bandung Model binaan telah mampu melakukan aktivitas pembelajaran, termasuk mengevaluasi kegiatan pembelajaran yang telah dilaksanakannya, secara variatif dengan lebih banyak mengandalkan kemampuan tim guru dalam team teaching.

Berdasarkan hasil kegiatan pelatihan program pembinaan karakter peserta didik di SMPK Bintang Mulia Mekar Wangi Bandung diperoleh model pembinaan yang tepat untuk membina para guru SMPK Bintang Mulia Mekar Wangi Bandung binaan pasca pelatihan dalam mewujudkan guru yang berkompeten, meliputi komponen (a) Inservice Training, (b) SMPK Bintang Mulia Mekar Wangi Bandung binaan, yang terdiri dan guru dan kepala sekolah, (c) pendampingan, (d) supervisi klinis, dan (e) evaluasi kinerja. Keseluruhan komponen yang ada merupakan bagian yang utuh (integral) terkait satu sama lain yang prosesnya bersifat sistemik. Setiap komponen merupakan awal dan kelanjutan dan komponen sebelumnya.

Secara umum motivasi guru di bidang perencanaan pembinaan karakter dapat digolongkan pada kategori cukup baik. Tingkat motivasi yang demikian dibuktikan oleh ketersediaan perangkat pembinaan yang sebagian besar 'diproduksi' oleh para guru yang melibatkan peserta didik. Kenyataan ini sungguh sangat menggembirakan, mengingat keterbatasan yang dimilikinya, guru di lingkungan SMPK Bintang Mulia Mekar Wangi Bandung binaan mencoba secara swadaya untuk memenuhi kebutuhannya, terutama di bidang perencanaan pembalajaran.

\section{DAFTAR PUSTAKA}

Alhairi. (2015). Penanaman Pendidikan Karakter bagi Siswa Berkebutuhan Khusus 'Tunagrahita' (Studi atas Siswa SMA-LB Negeri 1 Yogyakarta). Yogyakarta: Program Pascasarjana Universitas Negeri Sunan Kalijaga Yogyakarta.

Ansari, Rasid, Suwarni, Linda, Selviana, Rochmawati, dan Mawardi. (2020). "Media Komik Sebagai Alternatif Media Promosi Kesehatan Seksualitas Remaja". Jurnal IImiah Kesehatan, Volume 19 Nomor 01 Tahun 2020, h. 11. DOI: 10.33221/jikes.v19i01.431.

Hallahan, D.P., Kauffman, J.M., \& Pullen H. (2009). Exceptional Learners: Introduction to Special Education $11^{\text {th }}$ ed. USA: Pearson.

Hariyanto. (2018). "Menanamkan Kecerdasan Emosional Pada Anak Usia Dini Melalui Cerita dan Musik". Jurnal Edupedia Vol. 2, No. 2, Januari 2018 | 33, hal. 36.

Junihot M. Simanjuntak, Udin Syaefuddin Sa'ud, Aan Komariah, (2019). Model Pelatihan Berbasis Produk Untuk Meningkatkan Kinerja Penelitian dan Publikasi Karya IImiah, Jurnal Jaffray, Vol. 17, No. 1, April 2019, h. 112.

Junihot M. Simanjuntak. (2018). Belajar Sebagai Identitas Dan Tugas Gereja. Jurnal Jaffray, Vol. 16, No. 1, April 2018, h. 2.

Junihot M. Simanjuntak. (2017). IImu Belajar dan Didaktika Pendidikan Kristen. Yogyakarta: Penerbit ANDI.

Kemendikbud. (2014). Panduan Olimpiade Sains Nasional. Jakarta: Direktorat Jenderal Pendidikan Dasar, Kementerian Pendidikan dan Kebudayaan Indonesia.

Lickona, Thomas. (2013). Pendidikan Karakter Panduan Lengkap Mendidik Siswa Menjadi Pintar dan Baik. Bandung: Nusa Media.

Mubayidh, Makmun. (2006). Kecerdasan \& Kesehatan Emosional Anak. Jakarta: Pustaka AlKautsar.

Orange, T. \& L. O. (2005). The Media Diet for Kids. Jakarta: Serambi Ilmu Semesta. Serambi IImu Semesta.

Plucker, J. (2003) The Flynn Effect : http://www. indiana. edu/intel I/flynneffect.shtml\#Deary01. Diakses 11 Maret 2016, jam 9.43 WIB.

Setyaningrum, Yanur. (2011). Pendidikan Karakter Persektif Guru dan Psikolog. Malang: Selaras.

Shapiro, Lawrence E. (1997). Mengajarkan Emotional Intelligence Pada Anak. Jakarta: PT Gramedia Pustaka Utama.

Shimogaki, Kazuo. (1996). Kiri Islam antara Modernisme dan Postmodernisme: Telaah kritis Pemikiran Hasan Hanafi. Yogyakarta: LkiS

Susanto, Ahmad. (2016). Teori Belajar dan Pembelajaran. Jakarta: Prenadamedia Group,2016. 
Sudrajat, Ajat. (2011). Membangun Budaya Sekolah Berbasis Karakter Terpuji. Yogyakarta: UNY Press.

Toufexix, Anastasia. (1989). "Our Violent Kids". Time.

Ulfah, M. (2019). Pendekatan Holistik Integratif Berbasis Penguatan Keluarga pada Pendidikan Anak Usia Dini Full Day. Jurnal Obsesi : Jurnal Pendidikan Anak Usia Dini. https://doi.org/10.31004/obsesi.v4i1.255.

Wilson, Bryan R.. (1969). Religion in Secular Society, London: Penguin Books. 